DOI: 10.29413/ABS.2019-4.3.5

\title{
Pharmacogenetic Warfarin Dosing Algorithm in the Russian Population
}

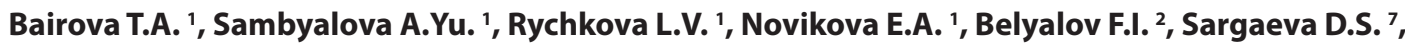
Shchedreeva E.A. ${ }^{4}$, Ignatyeva T.G. ${ }^{3}$, Ershova O.A. ${ }^{1}$, Pustozerov V.G. ${ }^{2,}{ }^{3}$, Kovaleva O.A. ${ }^{3}$, Rasputina I.V. ${ }^{4}$, Noskova I.A. ${ }^{5}$, Batogova T.V. ${ }^{4}$, Kuznetsova O.V. ${ }^{4}$, Bogoslova O.Yu. ${ }^{4}$, Kolesnikov S.I. ${ }^{1,6}$

1 Scientific Centre for Family Health and Human Reproduction Problems (ul. Timiryazeva 16, Irkutsk 664003, Russian Federation); 2 Irkutsk State Medical Academy of Postgraduate Education - Branch Campus of the Russian Medical Academy of Continuing Professional Education (Yubileyniy 100, Irkutsk 664049, Russian Federation); ${ }^{3}$ Regional Geriatric Centre (ul. Lenina 20A, Irkutsk 664025, Russian Federation); ${ }^{4}$ City Clinical Hospital N 10 (b. Ryabikova 31A, Irkutsk 664043, Russian Federation); ${ }^{5}$ Irkutsk Municipal

Polyclinic N 4 (Baikalskaya 109, Irkutsk 664047, Russian Federation); ${ }^{6}$ Lomonosov Moscow State University (Leninskie Gory 1, Moscow 119234, Russian Federation); ${ }^{7}$ Republican Clinical Hospital (Pavlova 12, Ulan-Ude 670031, Russian Federation)

Corresponding author: Alexandra Yu. Sambyalova, e-mail: sambialova95@mail.ru

\begin{abstract}
Background. To date, there are many pharmacogenetic algorithms for selecting the dose of warfarin. However, there is very little information about the predictive accuracy of the algorithms. We decided to evaluate the predictive accuracy of the Gage algorithm, using a calculator, located on the web site (http://www.warfarindosing.org) in two ethnic groups (Caucasians and Asians), living in Russia.

Aim. To compare the actual warfarin dose (AWD) to the calculated warfarin dose (CWD), using the algorithm in two ethnic groups taking warfarin.

Materials and methods. We included 114 patients (66 Caucasians and 48 Asians): the mean age was $60.91 \pm 12.34$ years; 61 (53.51\%) men, and 53 (46.49\%) women. The comparative characteristics of the algorithm were tested using the mean absolute error (MAE) between AWD and CWD, and percentage of patients, whose CWD fell within $20 \%$ of AWD (percentage within $20 \%$ ). Genotyping for CYP2C9*2, CYP2C9*3, CYP4F*2 and VKORC1 was performed by real-time polymerase chain reaction (RT-PCR) method using Pharmacogenetics Warfarin reagent kits (DNA technology, Russia).

Results. The Gage algorithm produced the predictive accuracy with $M A E=1.02 \pm 0.16 \mathrm{mg} /$ day and percentage within $20 \%$ for Asian patients was $39.6 \%$. We obtained MAE $=1.33 \pm 0.16 \mathrm{mg} /$ day and percentage within $20 \%$ for Caucasian patients was $40.9 \%$. In two ethnic groups (Caucasians and Asians) of the Russian population, overall performance of warfarin pharmacogenetic dosing by the Gage algorithm was similar.

Conclusions. Despite the performance limitation of the current warfarin pharmacogenetic dosing Gage algorithm, constant international normalized ratio monitoring is important.

Key words: warfarin, biotransformation, CYP2C9, CYP4F2, VKORC1, pharmacogenetics, personalized medicine, Caucasians, Asians
\end{abstract}

For citation: Bairova T.A., Sambyalova A.Yu., Rychkova L.V., Novikova E.A., Belyalov F.I., Sargaeva D.S., Shchedreeva E.A., Ignatyeva T.G., Ershova O.A., Pustozerov V.G., Kovaleva O.A., Rasputina I.V., Noskova I.A., Batogova T.V., Kuznetsova O.V., Bogoslova O.Yu., Kolesnikov S.I. Pharmacogenetic warfarin dosing algorithm in the Russian population. Acta biomedica scientifica. 2019; 4(3): 40-44. doi: 10.29413/ABS.2019-4.3.5

\section{Фармакогенетический алгоритм дозирования варфарина в российской популяции}

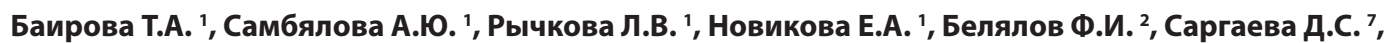

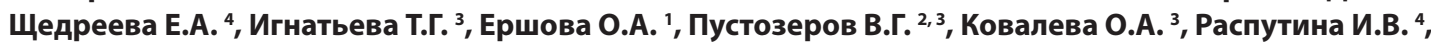 \\ Носкова И.А. ${ }^{5}$, Батогова Т.В. ${ }^{4}$, Кузнецова О.В. ${ }^{4}$, Богослова О.Ю. ${ }^{4}$, Колесников С.И. ${ }^{1,6}$
}

\begin{abstract}
'ФГБНУ «Научный центр проблем здоровья семьи и репродукции человека» (664003, г. Иркутск, ул. Тимирязева, 16, Россия);
2 Иркутская государственная медицинская академия последипломного образования - филиал ФГБОУ ДПО «Российская медицинская академия непрерывного профессионального образования» Минздрава России (664049, г. Иркутск, Юбилейный, 100, Россия); ${ }^{3}$ ГБУз «Областной гериатрический центр» (664025, г. Иркутск, ул. Ленина, 20а, Россия); ${ }^{4}$ ОГАУз «Городская клиническая больница № 10» (664043, г. Иркутск, б. Рябикова, 31А, Россия); ${ }^{5}$ ОГБУз «Иркутская городская поликлиника № 4» (664058, г. Иркутск, Первомайский, 23А, Россия); ${ }^{6}$ ФГБОУ ВО «Московский государственный университет имени М.В. Ломоносова» (1 19234, г. Москва, Ленинские Горы, 1, Россия); 7 Республиканская клиническая больница им. Н.А. Семашко (670031, г. Улан-Уде, ул. Павлова, 12, Россия)
\end{abstract}

Автор, ответственный за переписку: Самбялова Александра Юрьевна, e-mail: sambialova95@mail.ru

\section{Резюме}

Обоснование. На сегодняшний день существует множество фармакогенетических алгоритмов подбора дозы варфарина. Тем не менее, очень мало информации о прогностической точности алгоритмов в реальной клинической практике. Мы решили оценить прогностическую точность алгоритма Gage et al., с помощью размещенного калькулятора на сайте (http://www.warfarindosing.org) в двух этнических группах (европеоиды и азиаты) российской популяции.

Целью данной работы было сравнить фактическую дозу варфарина (AWD) с рассчитанной дозой варфарина (CWD) с использованием алгоритма в двух этнических группах, принимающих варфарин. 
Методы. Участники исследования - 114 пациентов (66 европеоидов, 48 азиатов), принимающих варфарин для профилактики тромбоэмболических осложнений: при фибриллящии предсердий - 92 (80,7 \%) человека, при ишемической болезни сердца - 7 (6,14\%), после тромбоза в анамнезе - $8(7,01 \%)$, при аритмии - $3(2,6 \%)$ и др. Средний возраст обследованных составил 60,91 \12,34 года; 61 (53,51\%) мужчина, 53 (46,49 \%) женщины. Сравнительные характеристики алгоритма были протестированы с использованием средней абсолютной ошибки (МАЕ) между фактической дозой варфарина и дозой, предсказанной с помощью алгоритма, и расчёта процента пациентов, у которых предсказанная доза не отличалась более чем на $20 \%$ от фактической дозы. Результаты. Фармакогенетический алгоритм Gage показал прогностическую точность с MAE 1,02 $\pm 0,16$ мг/ день и процент пациентов, у которых предсказанная доза не отличалась более чем на 20 \% от фактической

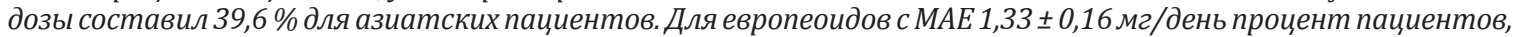
у которых предсказанная доза не отличалась более чем на $20 \%$ от фактической дозы, составил 40,9\%, что показало одинаковую производительность в двух этнических группах российской популяции.

Заключение. Прогностическая точность фармакогенетического калькулятора Gage et al. в реальной клинической практике в российской популящии невысокая, и поэтому всё еще важным при терапии варфарином является контроль международного нормализованного отношения (МНО).

Ключевые слова: варфарин, европеоиды, азиаты, СYР2C9, СYР4F2, фармакогенетика, персонализированная медицина

Для цитирования: Баирова Т.А., Самбялова А.Ю., Рычкова Л.В., Новикова Е.А., Белялов Ф.И., Саргаева Д.С., Щедреева Е.А., Игнатьева Т.Г., Ершова О.А., Пустозеров В.Г., Ковалева О.А., Распутина И.В., Носкова И.А., Батогова Т.В., Кузнецова О.В., Богослова О.Ю., Колесников С.И. Фармакогенетический алгоритм дозирования варфарина в российской популяции. Acta biomedica scientifica. 2019; 4(3): 40-44. doi: 10.29413/ABS.2019-4.3.5

\section{INTRODUCTION}

Warfarin is one of the most widely used oral anticoagulants in the treatment and prophylaxis of arterial and venous thromboembolic diseases [1, 2]. The warfarin has a narrow therapeutic range, its dosage is affected by genetic and non-genetic factors $[3,4]$. Non-genetic factors are gender, age, diet, race, concomitant drugs, body surface area (BSA) [5]. Genetic factors such as polymorphisms in the cytochrome P450 (CYP2C9), (CYP4F2) and the vitamin K epoxide reductase complex 1 (VKORC1) genes may also influence patient's response to warfarin $[6,7]$. Warfarin treatment is associated with interindividual variability in maintaining its effective dose, therapeutic warfarin doses differ between patients in 15-20 times [8]. High interindividual variability in warfarin doses has led to development of algorithms, scales, calculators for the selection of warfarin doses for anticoagulant therapy. Multiple genotype-based warfarin dosing algorithms have been published, however, the most cited is the Gage algorithm, since there is a simple calculator and it is freely available online (www.warfarindosing.org) [9]. The Gage algorithm is based on data from large, predominantly Caucasian, populations. This algorithm was derived from a population of over 1.000 patients, $83 \%$ of which were Caucasians, and $2 \%$ belonged to different races [10]. Little information is available on performance of published warfarin pharmacogenetic algorithms, and there is no data on performance of the Gage algorithm in Russian populations.

Aim of this study was to compare the actual warfarin dose (AWD) to the calculated warfarin dose (CWD), using the algorithm in two ethnic groups: Caucasians and Asians.

\section{MATERIALS AND METHODS}

The study was conducted from 2013 to 2018 years. We included patients with stable warfarin therapy. The study included 114 patients: 66 Caucasians and 48 Asians, 61 (53.51\%) men and 53 (46.49\%) women, mean age $60.91 \pm 12.34$ years. These patients were living in the Asian part of Russia (Irkutsk region and the Republic of Buryatia). They were diagnosed with: atrial fibrillation - 92 (80.7\%), coronary artery disease -7 (6.14\%), arrhythmia - $3(2.6 \%)$, thrombosis in a patient's medical history - 8 (7.01\%), no data - 4 (3.5\%). We had accessed the data from medical history, which included: smoking - 21 (18.42\%), taking amiodarone - 14 (12.28\%), and statins - 67 (58.77\%). Actual warfarin maintenance dose was defined as a stable dose for which the international normalized ratio (INR) measurements were within the therapeutic range (2-3) for the same mean daily dose during the last three clinic visits and is indicated as AWD in this study.

We excluded the patients if they had hepatic, thyroid (hypotheriosis or hyperthyreosis), renal diseases, decompensated heart failure, and patients taking warfarin interacting drugs, including Azoles and Trimethoprim-Sulfamethoxazole, because these drugs affected the metabolism of warfarin, and patients who did not comply with oral anticoagulant therapy (OAT).

Performance or percentage of compliance of the Gage algorithm was compared by calculating the percentage of patients, whose CWD was within $20 \%$ of AWD, and mean absolute error (MAE). We defined MAE as the mean value of the difference between CWD and AWD. We chose the percentage of patients within $20 \%$ of AWD (the percentage within $20 \%$ ), because a change in a warfarin dose greater than $20 \%$ may be considered clinically significant, and this change was used in other studies [11, 12].

The study was approved by the local Research Ethics Committee of Scientific Centre for Family Health and Human Reproduction Problems, and all patients provided informed consent to participate in the study.

Four ml of venous blood were collected in EDTA tube from each participant and processed for genomic DNA extraction. The subjects were genotyped for CYP2C9 $\left({ }^{*} 1,{ }^{*} 2,{ }^{*} 3\right)$, and CYP4F2 (1347C>T) and VKORC1 (1639 G>A) by real-time polymerase chain reaction (RT-PCR) using Pharmacogenetics Warfarin reagent kits (DNA technology, Russia).

\section{RESULTS}

We calculated CWD for each patient using the Gage algorithm (Table 1). Results showed that the algorithm produced similar performance between CWD and AWD, observed in real clinical practice, and in two ethnic groups taking warfarin. We discovered that Asian patients had mean AWD $=3.58 \pm 1.5$ and, when compared with mean $C W D=3.76 \pm 1.08$, we found no significant differences $(p=0.502)$. Mean AWD of the Caucasian patients was $4.02 \pm 1.9$, so we did not find significant differences by comparing it with mean CWD $=4.56 \pm 1.49(p=0.072)$. 
Performance of the Gage dosing algorithm in two ethnic groups (Caucasians and Asians) of the Russian population

\begin{tabular}{lccc}
\hline & $\begin{array}{c}\text { Daily warfarin dose } \\
\text { (mean AWD } \pm \text { SD) }\end{array}$ & $\begin{array}{c}\text { Daily warfarin dose } \\
\text { (mean CWD } \pm \text { SD*) }\end{array}$ & MAE (mg/day) \pm SE** \\
\hline All $(n=114)$ & $3.8 \pm 1.75$ & $4.22 \pm 1.38$ & $1.25 \pm 0.12$ \\
Asians $(n=48)$ & $3.58 \pm 1.5$ & $3.76 \pm 1.08$ & $1.02 \pm 0.16$ \\
Caucasians $(n=66)$ & $4.02 \pm 1.9$ & $4.56 \pm 1.49$ & $1.33 \pm 0.16$ \\
\hline
\end{tabular}

Note. *SD - Standard deviation, **SE - Standard error

The stable therapeutic dose was predicted with similar accuracy for two ethnic groups with $\mathrm{MAE}=1.33 \mathrm{mg} /$ day $(\mathrm{SE}=0.16)$ in our Caucasian cohort and with $\mathrm{MAE}=1.02 \mathrm{mg} /$ day $(\mathrm{SE}=0.16)$ in the Asian one $(p=0.184)$. We calculated the percentage of patients, AWD of who did not differ from CWD by more or less $20 \%$ in the Caucasian cohort (40.9\%) and similarly in the Asian cohort (39.58\%), ( $p=0,959)$. Comparison of the pharmacogenetic warfarin dosing using the Gage algorithm in two ethnic groups (Caucasians and Asians) of the Russian population showed that population overall performance of the algorithm was similar.

\section{DISCUSSION}

The history of the use of oral anticoagulants has more than half a century. Their effectiveness in the prevention of cardioembolic stroke was confirmed by clinical studies. However, warfarin therapy has several limitations: a"narrow therapeutic window", unpredictability of the anticoagulant response, interactions between food and drugs, and the need for regular international normalized ratio (INR) monitoring to maintain the effectiveness and safety of treatment. All the above stated determined the search for optimization of warfarin anticoagulant therapy, including the development of algorithms for drug therapy. One of the widely used algorithms is the calculator, developed by Gage et al. of the University of Washington in 2008.

In this study, we assessed the predictive accuracy of the pharmacogenetic warfarin dosing using the Gage algorithm, in real clinical practice in patients, living in the Asian part of Russia. The results indicated that the percentage within $20 \%$ in the general population was $42.2 \%$. No differences between doses were found in Caucasians and Asians (40.9\% and $39.58 \%$ respectively, $p=0.959$ ). Data from similar studies are variable. In previous study of E. Kropachyova et al., in 283 patients from the Russian population living in Moscow, Arkhangelsk, Vyatka, Nizhny Novgorod, Novosibirsk, St. Petersburg, Chelyabinsk, the percentage within $20 \%$ was $57 \%$ (we compared the percentage with our own study in the Caucasian population, $p=0.011$ ) [13]. Results, comparable to our data, were demonstrated by the researchers Jaekyu Shin and Diana Cao of the Department of Clinical Pharmacy San Francisco - 53.1\% $(p=0.071)$ [12]. Studies, conducted in the Turkish population, showed that the percentage within $20 \%$ was $29 \%$, and MAE $=2.25$ (SE $=0.23)$, which was significantly different from our results $(p=0.009)$ [14]. In the Asian population, we found that percentage within $20 \%$ was $39.58 \%$, which was comparable with the data of Shin et al., for a sample of Asian patients $-48.1 \%(p=0.33)$. The results indicated the low prognostic significance of the Gage algorithm, possibly due to differentiation of functional significance of warfarin metabolizing genes and their involvement in the formation of phenotypes in different racial, ethnic and territorial populations.

\section{CONCLUSIONS}

The Gage algorithm was based on a mixed population and therefore we did not get the predictive accuracy of significant differences in two ethnic groups (Caucasians and Asians) of the Russian population. In conclusion, despite performance limitation of the current warfarin pharmacogenetic dosing using the Gage algorithm, close INR monitoring is essential.

\section{Conflict of interests}

The authors report no conflicts of interest in this work.

\section{ЛИТЕРАТУРА}

1. Баирова Т.А., Новикова Е.А., Белялов Ф.И., Щедреева Е.А., Иевлева К.Д., Калюжная О.В., и др. Распространённость полиморфизмов генов цитохромов Р450-метаболизаторов варфарина в Восточной Сибири. Acta biomedical scientifica. 2018; 3(5): 39-48. doi10.29413/ ABS.2018-3.5.6

2. Lemesle G, Ducrocq G, Elbez Y, Van Belle E, Goto S, Cannon CP, et al. Vitamin K antagonists with or without longterm antiplatelet therapy in outpatients with stable coronary artery disease and atrial fibrillation: association with ischemic and bleeding events. Clin.Cardiol. 2017; 40(10): 932-939. doi: $10.1002 /$ clc. 22750

3. Rieder MJ, Reiner AP, Gage BF, Nickerson DA, Eby CS, McLeod HL, et al. Effect of VKORC1 haplotypes on transcriptional regulation and warfarin dose. N Engl J Med. 2005; 352(22): 2285-2293. doi: 10.1056/NEJMoa044503

4. Wadelius M, Pirmohamed M. Pharmacogenetics of warfarin: current stat and future challenges. Pharmacogenomics J. 2007; 7(2): 99-111. doi: 10.1038/sj.tpj.6500417

5. Loebstein R, Yonath H, Peleg D, Almog S, Rotenberg $M$, Lubetsky $A$, et al. Interindividual variability in sensitivity to warfarin - Nature or nurture? Clin Pharmacol Ther. 2001; 70(2): 159-164. doi: 10.1067/mcp.2001.117444

6. Ayesh BM, Abu Shaaban AS, Abed AA. Evaluation of CYP2C9- and VKORC1-based pharmacogenetic algorithm for warfarin dose in Gaza-Palestine. Future Science OA, 2018; 4(3): FSO276. doi:10.4155/fsoa-2017-0112

7. Rychkova LV, Bairova TA, Novikova EA, Sargaeva DS, levleva KD, Kalyuzhnaya OV, et al. Prediction of bleeding complications during warfarin intake. In: Poster Session 2. European Journal of Preventive Cardiology. 2018; 25 (2suppl): S72-S105. doi: 10.1177/2047487318786182

8. Higashi MK, Veenstra DL, Kondo LM, Wittkowsky AK, Srinouanprachanh SL, Farin FM, et al. Association between CYP2C9 genetic variants and anticoagulation-related outcomes during warfarin therapy. JAMA. 2002; 287(13): 16901698. doi:10.1001/jama.287.13.1690

9. Gage BF, Eby C, Johnson JA, Deych E, Rieder MJ, Ridker PM, et al. Use of pharmacogenetic and clinical factors to predict the therapeutic dose of warfarin. Clin Pharmacol Ther. 2008; 84(3): 326-331. doi: 10.1038/clpt.2008.10 
10. Selim TE, Azzam HA, Ghoneim HR, Mohamed AA, El Wakeel $\mathrm{H}$, Abu Bakr HM. Pharmacogenetic warfarin dosing algorithms: validity in Egyptian patients. Acta Haematologica. 2018; 139(4): 255-262. doi:10.1159/000486889

11. The International Warfarin Pharmacogenetics Consortium. Estimation of the warfarin dose with clinical and pharmacogenetic data. N Engl J Med. 2009; 360: 753-764. doi: 10.1056/NEJMoa0809329

12. Shin J, Cao D. Comparison of warfarin pharmacogenetic dosing algorithms in a racially diverse large cohort. Pharmacogenomics, 2011; 12(1): 125-134. doi:10.2217/ pgs.10.168

13. Кропачева Е.С. Фармакогенетика варфарина. Атеротромбоз. 2015; (1): 107-111. doi: 10.21518/2307-11092015-1-107-111

14. Karaca S, Bozkurt NC, Cesuroglu T, Karaca M, Bozkurt M, Eskioglu $E$, et al. International warfarin genotype-guided dosing algorithms in the Turkish population and their preventive effects on major and life-threatening hemorrhagic events. Pharmacogenomics. 2015; 16(10): 11091118. doi:10.2217/pgs. 15.58

\section{REFERENCES}

1. Bairova TA., Novikova EA, Belyalov Fl, Shchedreeva EA, levleva KD, Kalyuzhnaya OV, et al. Frequencies of polymorphisms in the cytochrome's P450 genes of warfarin transformation in a European population of Eastern Siberia. Acta biomedical scientifica. 2018; 3(5): 39-48. doi10.29413/ ABS.2018-3.5.6 (In Russ.)

2. Lemesle G, Ducrocq G, Elbez Y, Van Belle E, Goto S, Cannon CP, et al. Vitamin K antagonists with or without longterm antiplatelet therapy in outpatients with stable coronary artery disease and atrial fibrillation: association with ischemic and bleeding events. Clin.Cardiol. 2017; 40(10): 932-939. doi: $10.1002 /$ clc. 22750

3. Rieder MJ, Reiner AP, Gage BF, Nickerson DA, Eby CS, McLeod HL, et al. Effect of VKORC1 haplotypes on transcriptional regulation and warfarin dose. $N$ Engl J Med. 2005; 352(22): 2285-2293. doi: 10.1056/NEJMoa044503

4. Wadelius M, Pirmohamed M. Pharmacogenetics of warfarin: current stat and future challenges. Pharmacogenomics J. 2007; 7(2): 99-111. doi: 10.1038/sj.tpj.6500417
5. Loebstein R, Yonath H, Peleg D, Almog S, Rotenberg $M$, Lubetsky $A$, et al. Interindividual variability in sensitivity to warfarin - Nature or nurture? Clin Pharmacol Ther. 2001; 70(2): 159-164. doi: 10.1067/mcp.2001.117444

6. Ayesh BM, Abu Shaaban AS, Abed AA. Evaluation of CYP2C9- and VKORC1-based pharmacogenetic algorithm for warfarin dose in Gaza-Palestine. Future Science OA, 2018; 4(3): FSO276. doi:10.4155/fsoa-2017-0112

7. Rychkova LV, Bairova TA, Novikova EA, Sargaeva DS, levleva KD, Kalyuzhnaya OV, et al. Prediction of bleeding complications during warfarin intake. In: Poster Session 2. European Journal of Preventive Cardiology. 2018; 25 (2suppl): S72-S105. doi: $10.1177 / 2047487318786182$

8. Higashi MK, Veenstra DL, Kondo LM, Wittkowsky AK, Srinouanprachanh SL, Farin FM, et al. Association between CYP2C9 genetic variants and anticoagulation-related outcomes during warfarin therapy. JAMA. 2002; 287(13): 16901698. doi:10.1001/jama.287.13.1690

9. Gage BF, Eby C, Johnson JA, Deych E, Rieder MJ, Ridker PM, et al. Use of pharmacogenetic and clinical factors to predict the therapeutic dose of warfarin. Clin Pharmacol Ther. 2008; 84(3): 326-331. doi: 10.1038/clpt.2008.10

10. Selim TE, Azzam HA, Ghoneim HR, Mohamed AA, El Wakeel $\mathrm{H}$, Abu Bakr HM. Pharmacogenetic warfarin dosing algorithms: validity in Egyptian patients. Acta Haematologica. 2018; 139(4): 255-262. doi:10.1159/000486889

11. The International Warfarin Pharmacogenetics Consortium. Estimation of the warfarin dose with clinical and pharmacogenetic data. N Engl J Med. 2009; 360: 753-764. doi: 10.1056/NEJMoa0809329

12. Shin J, Cao D. Comparison of warfarin pharmacogenetic dosing algorithms in a racially diverse large cohort. Pharmacogenomics, 2011;12(1): 125-134. doi:10.2217/pgs.10.168

13. Kropacheva ES. Pharmacogenetics of warfarine. Aterotromboz. 2015; (1): 107-111. doi: 10.21518/2307-11092015-1-107-111(In Russ.)

14. Karaca S, Bozkurt NC, Cesuroglu T, Karaca M, Bozkurt M, Eskioglu $E$, et al. International warfarin genotype-guided dosing algorithms in the Turkish population and their preventive effects on major and life-threatening hemorrhagic events. Pharmacogenomics. 2015; 16(10): 11091118. doi:10.2217/pgs. 15.58

\footnotetext{
Сведения об авторах

Баирова Татьяна Ананьевна - доктор медицинских наук, руководитель лаборатории персонализированной медицины ФГБНУ «Научный центр проблем здоровья семьи и репродукции человека», e-mail: tbairova38@mail.ru, https://orcid.org/0000-0003-3704-830X

Самбялова Александра Юрьевна - младший научный сотрудник лаборатории персонализированной медицины ФГБНУ «Научный центр проблем здоровья семьи и репродукции человека», е-mail: sambialova95@mail.ru, https://orcid.org/0000-0001-5790-6282

Рычкова Любовь Владимировна - доктор медицинских наук, профессор, директор ФГБНу «Научный центр проблем здоровья семьи и репродукции человека», e-mail: iphr@sbamsr.irk.ru

Новикова Евгения Анатольевна - аспирант ФГБНу «Научный центр проблем здоровья семьи и репродукции человека», e-mail: europe411@mail.ru, https://orcid. org/0000-0002-9353-7928

Белялов Фарид Исмагильевич - доктор медицинских наук, профессор кафедры геронтологии и гериатрии, руководитель Кардиоаритмологического центра Иркутской государственной медицинской академии последипломного образования - филиала ФГБОУ дПО «Российская медицинская академия непрерывного профессионального образования» Минздрава России, https://orcid.org/0000-0001-9131-6534

Саргаева Дарима Сергеевна - врач Республиканской клинической больницы им. Н.А. Семашко, e-mail: darimaSargaeva@mail.ru

Щедреева Елена Анатольевна - врач ОГАУЗ «Городская клиническая больница № 10»

Игнатьева Татьяна Геннадьевна - врач-кардиолог ГБУз «0бластной гериатрический центр»

Ершова Оксана Александровна - кандидат биологических наук, научный сотрудник лаборатории персонализированной медицины ФГБНУ «Научный центр проблем здоровья семьи и репродукции человека», e-mail: oksana111088@mail.ru

Пустозеров Виктор Георгиевич - кандидат медицинских наук, главный врач ГБУз «0бластной гериатрический центр», заведующий кафедры геронтологии и гериатрии Иркутской государственной медицинской академии последипломного образования - филиала ФГБОУ дПО «Российская медицинская академия непрерывного профессионального образования» Минздрава России, e-mail: Dr.Pystozerov@bk.ru

Ковалева Ольга Анатольевна - врач ГБУЗ «Областной гериатрический центр»
} 
Распутина Ирина Викторовна - врач ОГАУЗ «Городская клиническая больница № 10» Носкова Инетта Александровна - врач ОГБУЗ «Иркутская городская поликлиника № 4» Батогова Татьяна Васильевна - врач ОГАУЗ «Городская клиническая больница № 10» Кузнецова Ольга Валерьевна - врач ОГАУЗ «Городская клиническая больница № 10» Богослова Ольга Юрьевна - врач ОГАУЗ «Городская клиническая больница № 10» Колесников Сергей Иванович - академик РАН, заместитель главного учёного секретаря Президиума РАН, професcop MГУ им. M.B. Ломоносова, e-mail: Sikolesnikov2012@ gmail.com, https://orcid.org/0000-0003-2124-6328

\section{Information about the authors}

Tatiana A. Bairova - Dr. Sc. (Med.), Head of the Laboratory of Personalized Medicine, Scientific Centre for Family Health and Human Reproduction Problems, e-mail: tbairova38@ mail.ru, https://orcid.org/0000-0003-3704-830X

Alexandra Yu. Sambyalova - Junior Research Officer at the Laboratory of Personalized Medicine, Scientific Centre for Family Health and Human Reproduction Problems, e-mail: sambialova95@mail.ru, https://orcid.org/0000-0001-5790-6282

Lyubov V. Rychkova - Dr. Sc. (Med.), Professor, Director of Scientific Centre for Family Health and Human Reproduction Problems, e-mail: iphr@sbamsr.irk.ru

Evgeniya A. Novikova - Postgraduate at Scientific Centre for Family Health and Human Reproduction Problems, e-mail: europe411@mail.ru, https://orcid.org/0000-0002-9353-7928 Farid I. Belyalov - Dr. Sc. (Med.), Professor of the Department of Gerontology and Geriatrics, Head of Cardiac Center, Irkutsk State Medical Academy of Postgraduate Education - Branch Campus of the Russian Medical Academy of Continuing Professional Education, https://orcid.org/0000-0001-9131-6534

Darima S. Sargaeva - Physician, Republican Clinical Hospital, e-mail: darimaSargaeva@mail.ru

Elena A. Shchedreeva - Physician, City Clinical Hospital N 10

Tatyana G. Ignatyeva - Physician, Regional Geriatric Centre

Oksana A. Ershova - Cand. Sc. (Biol.), Research Officer at the Laboratory of Personalized Medicine, Scientific Centre for Family Health and Human Reproduction Problems, e-mail: oksana111088@mail.ru

Viktor G. Pustozerov - Cand. Sc. (Med.), Chief Physician of Regional Geriatrics Center; Head of the Department of Gerontology and Geriatrics, Irkutsk State Medical Academy of Postgraduate Education - Branch Campus of the Russian Medical Academy of Continuing Professional Education, e-mail: Dr.Pystozerov@bk.ru

Olga A. Kovaleva - Physician, Regional Geriatrics Center

Irina V. Rasputina - Physician, City Clinical Hospital N 10

Inetta A. Noskova - Physician, Irkutsk Municipal Polyclinic N 4

Tatyana V. Batogova - Physician, City Clinical Hospital N 10

Olga V. Kuznetsova - Physician, City Clinical Hospital N 10

Olga Yu. Bogoslova - Physician, City Clinical Hospital N 10

Sergei I. Kolesnikov-Academician of RAS, Deputy Chief Secretary of Russian Academy of Sciences Presidium, Professor of Lomonosov Moscow State University, e-mail:Sikolesnikov2012@ gmail.com, https://orcid.org/0000-0003-2124-6328

\section{Вклад авторов}

Баирова Т.А. - формирование идеи, дизайна, организации исследования

Самбялова А.Ю. - статистическая обработка, написание статьи

Рычкова Л.В. - согласование статьи

Новикова Е.А. - подготовка обзора литературь

Белялов Ф.И. - участие в формировании дизайна

Саргаева Д.С. - набор пациентов

Щедреева Е.А. - набор пациентов

Игнатьева Т.Г. - набор пациентов;

Ершова 0.А. - проведение лабораторных исследований

Пустозеров В.Г. - набор пациентов

Ковалева 0.А. - проведение лабораторных исследований

Распутина И.В. - набор пациентов

Носкова И.А. - набор пациентов

Батогова Т.В. - набор пациентов

Кузнецова О.В. - набор пациентов

Богослова 0.Ю. - набор пациентов

Колесников С.И. - формирование концепции направления исследования 